\title{
Vehicle Fleet Management Practices and Service Delivery in State Owned Enterprises in Zimbabwe
}

\author{
John Promise Chiparo, Marian Tukuta, Michael Musanzikwa \\ Department of Logistics and Transport, Harare, Zimbabwe \\ Email: chiparopj@gmail.com
}

How to cite this paper: Chiparo, J.P., Tukuta, M. and Musanzikwa, M. (2022) Vehicle Fleet Management Practices and Service Delivery in State Owned Enterprises in Zimbabwe. Journal of Transportation Technologies, 12, 159-171.

https://doi.org/10.4236/jtts.2022.122010

Received: January 11, 2022

Accepted: March 1, 2022

Published: March 4, 2022

Copyright $\odot 2022$ by author(s) and Scientific Research Publishing Inc. This work is licensed under the Creative Commons Attribution International License (CC BY 4.0).

http://creativecommons.org/licenses/by/4.0/ (c) (i) Open Access

\begin{abstract}
The main objective of the study was to examine the influence of vehicle fleet management practices on service delivery in State-Owned Enterprises (SOEs) in Zimbabwe. The study adopted a pragmatism research philosophy together with a mixed method research paradigm. In addition, structured questionnaires were distributed to 344 respondents drawn from 86 SOEs. Stratified and purposive sampling was used. Descriptive statistics were calculated using Statistical Package for the Social Science (SPSS) version 20. Exploratory factor analysis (EFA) was done on all items of the study while research hypotheses were tested using Structural Equation Modelling (SEM) in AMOS version 21. The study concluded that vehicle maintenance, fuel management, driver management and vehicle replacement positively influence service delivery. In addition, the study also established that Information and Communication Technologies (ICTs) moderate the influence of vehicle fleet management practices on service delivery. The study recommended that there is need for regular driver training and vehicle programs encompassing electronic spares tracking.
\end{abstract}

\section{Keywords}

Fleet, Service Delivery, Management, State-Owned Enterprises

\section{Introduction}

Over the years several economies around the globe have relied on State-Owned Enterprises (SOEs) in spearheading notable economic growth, creating jobs, curbing poverty, significantly contributing to the nation's Gross Domestic Product (GDP) and offering equitable sustainable development, [1]. In the Organization 
for Economic Co-operation and Development (OECD) area, SOEs account for as much as $10 \%$ of economic activity, [2]. In the People's Republic of China (PRC) SOEs account for about 30\% of GDP, 38\% in Viet Nam, 25\% in India and Thailand, and about 15\% in Malaysia and Singapore, more than 50\% of GDP in Tajikistan, Turkmenistan and Uzbekistan and about 20\% - 40\% in other Central Asian countries respectively, [3]. Notwithstanding their contribution to economic development and prosperity, a relatively well-developed body of literature shows that most SOEs are underperforming, [4].

Ref. [5] observed that the root causes of poor performance in SOEs are related to misalignment of practices and strategies. In a similar way, [6] assert that in most countries across the globe there is a substantial misalignment between SOEs' current supply chain management practices and the government supply chain management legislative environment, resulting in weaknesses in controls, poor compliance, poor policy implementation and missed transformation targets. For the same reason, [7] has pointed out that weak logistics practices particularly vehicle fleet management have caused delays in the implementation of government services and projects, thereby derailing service. Most SOEs globally, are faced with shrinking budget facilities while at the same time, having to provide the most suitable fleet in support of core service delivery requirements, [8]. In the same way, public sector fleet management in many African countries, have in spite of good intentions, generally been less efficient than private firms, [9].

Despite adopting technology, most SOEs in South Africa face serious challenges in implementing service delivery options that enhance existing structures towards service delivery, [10]. Ref. [11], found that there have been a number of unnecessary purchases of motor vehicles in many public entities in Tanzania, though those extra vehicles bought do not reflect the exact demand. Correspondingly, [12], shows that the Tanzanian government has been losing almost 350 motor vehicles every year due to being out of order and lack of effective maintenance systems in public entities. The report further shows that the public entities have been incurring more than four billion shillings (1,725,910.80 United States Dollars), just for fleet purchases and maintenance. Ref. [13], observed that public entities are challenged by frequent vehicular breakdowns, accidents as well as poor vehicular scheduling. Ref. [14], argues that even though there are laws and policies framework governing fleet operations, there is non-compliance to asset management regulations in public entities.

Similarly, SOEs in Zimbabwe suffer from gross mismanagement, corruption and poor service delivery, [15] [16] [17]. In the same way, [18], observed that SOEs became extensions of political patronage and havens of corrupt practices and mismanagement of public assets. [19] and [20], posit that SOEs are plagued with increasing costs in vehicle repair and maintenance, fuel theft, aging fleet, poor vehicle financing, disposal, non-compliance to procurement procedures and rampant misuse of state vehicles. For instance, ZINARA purchased 40 graders worth $\$ 8$ million which are unsuitable for use under local climates since they 
were fitted with snow ploughs, [18]. The same report also shows that Central Mechanical Department's (CMED) \$3 million tender was awarded to First Oil Company to deliver diesel but this deal turned sour when the fuel was never delivered. [21], confirmed that Air Zimbabwe has only five operational aircraft and nearly 50 pilots who have to take turns to fly them. The National Railways of Zimbabwe (NRZ) is a pale shadow of its former self currently operating below $10 \%$ capacity utilization and has not been paying its workers for the past three consecutive years Zimbabwe, [22]. As a result of these malpractices, service delivery of SOEs has fallen far short of what is required by the economy and the general public, [23]. Therefore, this study focused on the influence of vehicle fleet management practices on service delivery in SOEs.

\section{Methodology}

The study adopted a pragmatism research philosophy which afforded researchers the freedom of choice to apply the best methods to execute the research to collect more credible results. [24], notes that pragmatism allows the researcher to view the topic from different views with regards to the influence of social actors and uses these to create a practical approach to research. In light of the pragmatic approach, a mixed method approach was used. Ref. [25], asserted that the mixed approach is a product of the pragmatist paradigm that combines the qualitative and quantitative approaches within different phases of the research process. The researcher opted for a cross-sectional survey considering that it provides: precise results, good statistical significance, high representativeness, convenient data gathering and little observer subjectivity.

The target population was comprised of 107 SOEs in Zimbabwe, [22]. Conferring to Krejcie and Morgan's (1970) formula the sample size was 86 SOEs at $95 \%$ confidence level. Each SOE was given four questionnaires giving a grand total of 344 structured questionnaires. Structured questionnaires were distributed to Directors, Transport Managers, Transport Administrators, Transport Officers, Fuel Attendants, Drivers, and Mechanics. The study used stratified, convenience and purposive sampling. The researchers used stratified sampling to successfully divide the target population into homogeneous groups so that all elements of the population were well represented in the sample. In addition, purposive sampling was used to pick 25 key informants such as Directors, Transport Managers and Transport Administrators. Key informants were selected based on their knowledge on vehicle fleet management practices and service delivery. Completed questionnaires were then checked for correct responses and eligibility of participants. Descriptive statistics were calculated using Statistical Package for the Social Science (SPSS) version 20. Exploratory factor analysis (EFA) was done on all items of the study while research hypotheses were tested using Structural Equation Modelling (SEM) in AMOS version 21.

\section{Results}

Before conducting a structural equation modelling (SEM) to test research hypo- 
theses, data was validated through exploratory factor analysis (EFA), reliability analysis, convergent validity, and discriminant validity. Prior to performing EFA, the sustainability of data for factor analysis was evaluated using Kaiser Meyer Olkin Measure of Sampling Adequacy (KMO) and Bartlett's Test of Sphericity using SPSS Version 20. KMO statistic of 0.606, a chi-square of 851.925 and degrees of freedom $[D F]$ of $435 ; p<0.001$ were obtained indicating that the sample was suitable to perform EFA as recommended by [26]. Adding to that, the rotated component matrix solution gave six (6) components namely vehicle maintenance (VM), fuel management (FM), driver management (DM), vehicle replacement (VR), service delivery (SD) and information and communication technology (ICT). The total variance explained of $64.441 \%$ was registered which was way above the recommended limit of $60 \%$ [27]. To test the extent to which variables in a study are consistent with what they are supposed to measure, reliability analysis was performed. The Internal consistency of constructs was measured using the Cronbach's Alpha $(\alpha)$. Reliabilities of the study's constructs are represented in Table 1.

Table 1 shows that all constructs had a Cronbach's alpha $(\alpha)$ of more than 0.6 as recommended by [28]. After conducting reliability analysis, the researcher performed convergent analysis to ensure that no construct correlates with other different concepts. Before determining convergent validity, a measurement model was first assessed to ensure that it was fit for testing. Maximum Likelihood Estimation (MLE) was used to estimate the measurement model so as to acquire better estimates [26]. CMIN/DF ( $\chi 2 / D f)$, Goodness of Fit Index (GFI), Adjusted GFI (AGFI), Normed Fit Index (NFI), Tucker-Lewis Index (TLI), Comparative Fit Index (CFI) and Root Mean Square Error of Approximation (RMSEA) were considered in determining the measurement model fit indices. The measurement model indicated appropriate model fit indices $(\mathrm{CMIN} / / \mathrm{DF}=$ 4.619; $\mathrm{GFI}=0.899 ; \mathrm{AGFI}=0.871 ; \mathrm{NFI}=0.939 ; \mathrm{TLI}=0.944 ; \mathrm{CFI}=0.952$ and RMSEA $=0.071) .[29]$, recommended that a good model should show a $\chi 2 / D F$ between the scales 0 - 5 with smaller values indicating a better fit. [30], suggested that values for GFI, AGFI, NFI, TLI and CFI specify a good fit when they are closer to 1 , and RMSEA must be between 0.05 and 0.10 for it to be satisfactory.

Table 1. Construct, number of items and Cronbach's $(\alpha)$.

\begin{tabular}{ccc}
\hline Construct & Number of Items & Cronbach's alpha $(\alpha)$ \\
\hline VM & 5 & 0.753 \\
FM & 5 & 0.681 \\
DM & 5 & 0.785 \\
VR & 5 & 0.887 \\
SD & 5 & 0.834 \\
ICT & 5 & 0.725 \\
\hline
\end{tabular}

Source: Research data 2021. 
In addition, all items had standardized factor loadings $(\lambda)$ above the cut-off point of 0.6 [28] [31]. Critical ratios (CRs) were appropriately large and significant at $\mathrm{p}<0.001$ indicating that the minimum requirements for convergent validity were satisfied. Average variance extracted (AVEs) were used to measure discriminant validity through comparing them against squared inter-construct correlations (SICCs). Table 2 shows the conditions for discriminant validity.

Discriminant validity is acceptable if average variance extracted results are greater than the squared inter-construct correlations [32]. Results in Table 2 indicate that conditions essential for fulfilling discriminant validity were satisfied since they were all greater than 0.5 and also greater than their corresponding squared inter-construct correlations. Henceforth, conditions necessary to achieve discriminant validity were satisfied.

\section{Hypothesis Testing}

The study tested the hypotheses in order to accept as true or reject as false the acclaimed statements or associations between variables [33]. Vehicle Fleet Management Practices was treated as a second order construct because it is multidimensional. Hypothesized relationships $\left(\mathrm{H}_{1}, \mathrm{H}_{2}, \mathrm{H}_{3}, \mathrm{H}_{4}\right.$ and $\left.\mathrm{H}_{5}\right)$ were tested in AMOS version 21 using structural equation modelling (SEM) technique. Maximum Likelihood Estimation (MLE) was used to estimate the structural model [26]. The structural model indicated satisfactory model fit indices $(\mathrm{CMIN} / / \mathrm{DF}=$ 1.89; $\mathrm{GFI}=0.899 ; \mathrm{AGFI}=0.903 ; \mathrm{NFI}=0.910 ; \mathrm{TLI}=0.896 ; \mathrm{CFI}=0.919$ and RMSEA $=0.147)$. Table 3 shows results of hypotheses tests.

Table 2. AVEs and SICCs.

\begin{tabular}{ccccccc}
\hline Construct & VM & FM & DM & VR & SD & ICT \\
\hline VM & $\mathbf{0 . 4 9 7}$ & & & & & \\
VF & 0375 & $\mathbf{0 . 5 0 7}$ & & & & \\
DM & 0.225 & 0.386 & $\mathbf{0 . 5 6 3}$ & & & \\
VR & 0.361 & 0.208 & 0.311 & $\mathbf{0 . 6 3 0}$ & & \\
SD & 0.221 & 0.208 & 0.251 & 0.403 & $\mathbf{0 . 5 8 1}$ & \\
ICT & 0.427 & 0.301 & 0.297 & 0.511 & 0.380 & $\mathbf{0 . 4 9 5}$ \\
\hline
\end{tabular}

Note: diagonal elements in bold represent AVEs. Source: Research Data (2021).

Table 3. Summary of Hypothesis testing results.

\begin{tabular}{ccccc}
\hline Hypothesis & Hypothesised Relationship & SRW & CR & Remark \\
\hline $\mathrm{H}_{1}$ & Vehicle maintenance $\rightarrow$ service delivery & 0.227 & $13.025^{\star * *}$ & Supported \\
$\mathrm{H}_{2}$ & Vehicle fuel management $\rightarrow$ Service delivery & 0.309 & $11.078^{* * *}$ & Supported \\
$\mathrm{H}_{3}$ & Driver management $\rightarrow$ service delivery & 0.298 & $9.782^{* * *}$ & Supported \\
$\mathrm{H}_{4}$ & Vehicle Replacement $\rightarrow$ service delivery & 0.407 & $12.312^{\star * *}$ & Supported \\
\hline
\end{tabular}

Notes: SRW standardized regression weight, CR critical ratio, ${ }^{\star \star}$ significant at $\mathrm{p}<0.05$, ${ }^{* * *}$ significant at $\mathrm{p}<0.001$. Source: Research Data (2021). 
Table 3 shows that $\mathrm{H}_{1}, \mathrm{H}_{2}, \mathrm{H}_{3}$ and $\mathrm{H}_{4}$ were statistically supported. The implication of this finding is that there is sufficient statistical support that vehicle maintenance (VM), vehicle fuel management (FM), driver management (DM and vehicle replacement (VR) influence service delivery (SD). The study also sought to evaluate the moderating effect of ICT on the relationship between vehicle fleet management practices and service delivery. Based on the regression method, the results are presented in Table 4 . The analysis shows that the interaction between vehicle fleet management practices and ICT is statistically significant $(t=5.031$, $\mathrm{p}<0.05)$. This shows that ICT significantly moderated the influence of vehicle fleet management practices on service delivery in SOEs. The proposed structural model is depicted in Figure 1.

As can be seen on Figure 1, ICT strengthens the positive relationship between vehicle fleet management practices and service delivery. Thus the relationship will be stronger when the level of ICT usage is increased.

Table 4. Moderated regression results for ICT.

\begin{tabular}{cccc}
\hline Variable & Beta & t-statistic & p value \\
\hline Information Communication Technology & 0.759 & 5.031 & 0.000 \\
\hline
\end{tabular}

Source: Research Data (2021).

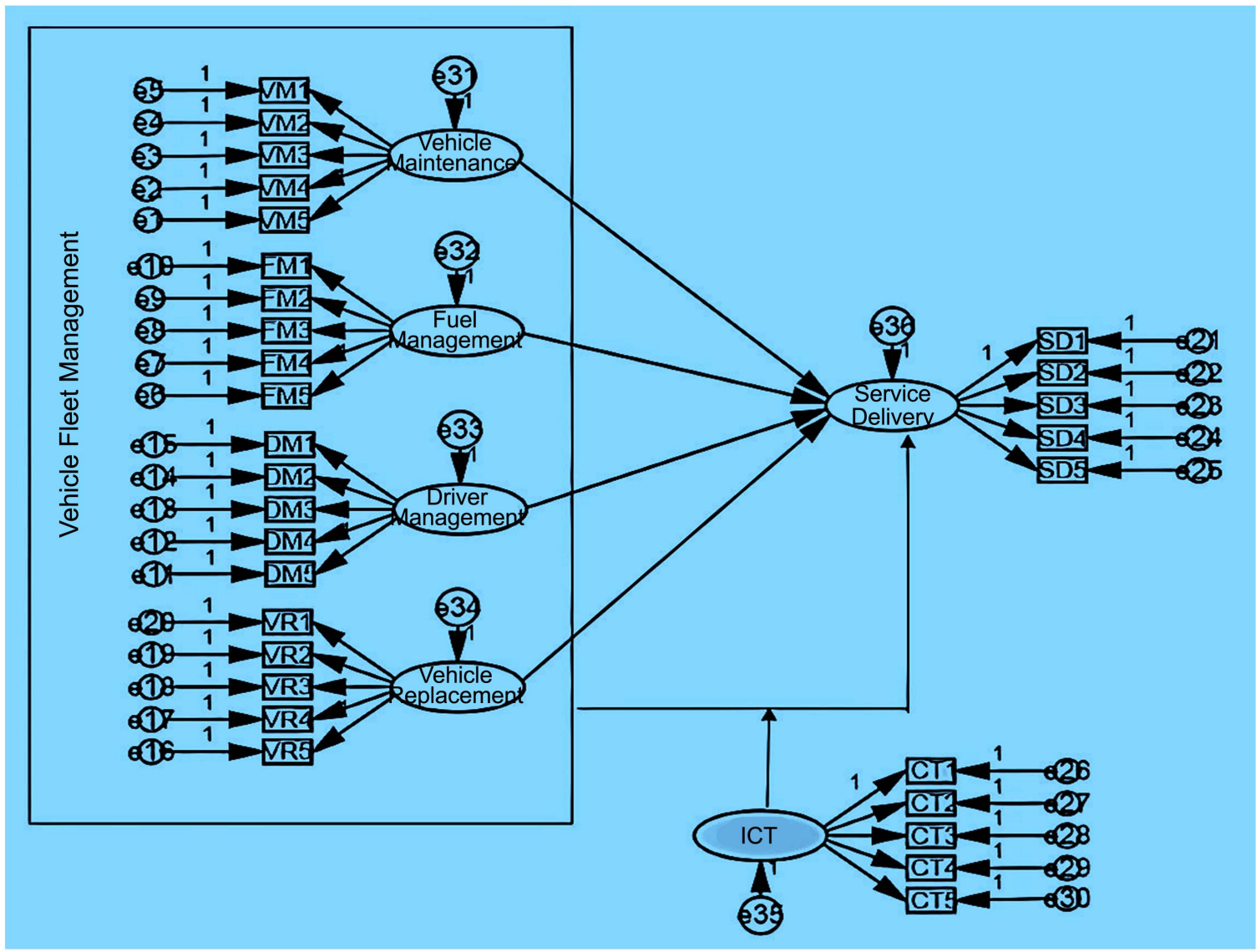

Figure 1. Model 1. Source: Survey Data (2021). 


\section{Discussion}

The discussions of results in this section are premised mainly on the hypotheses of the study. The results provide adequate confirmation that vehicle maintenance has a positive effect on service delivery. The implication of this finding is that continuous improvement in vehicle maintenance and spare parts availability improve service delivery. If SOEs fail to adhere to these maintenance requirements, they may not be reliable and responsive to their customer needs. This is in conformity with the other earlier studies such as those of [13] [34] [35] [36] [37], which proved that vehicle maintenance has a positive impact on service delivery. This strengthens the position of this finding thus $\mathrm{H}_{1}$ was supported. Secondly, the results provide adequate confirmation that vehicle fuel management has a positive effect on service delivery. This suggests that fuel management influences fuel sourcing, tyre management, fuel allocation and monitoring influence service delivery within SOEs. Many studies have applauded vehicle fuel management as a key component of fleet management that facilitates the movement of vehicles at any point in time [34] [37] [38] [39]. The study findings revealed that there is lack of transparency in fuel procurement. This is confirmed by findings of [18] who also observed that there was rampant corruption in the award of fuel tenders in SOEs in Zimbabwe. Ref. [40], assert that there is lack of accountability and transparency in the allocation of resources in the public sector. In addition, the findings also established that there are loopholes in fuel consumption and allocation mechanisms. It is important that public entities institute the right measures that promote efficient management of fuel since it has major impact on the service delivery, [41]. In line with these studies, the assumption that vehicle fuel management positively influences service delivery was confirmed in this study, which means $\mathrm{H}_{2}$ was supported.

The study results indicate that driver management positively influences service delivery. This implies that driver recruitment procedures, driver behavior, training and recognition influences service delivery. A number of empirical studies have reached similar findings [34] [35] [37] [39] [42]. This consolidates the position of this finding, thus $\mathrm{H}_{3}$ was supported. Organizations should ensure that, it obtains and retains skilled, committed and well-motivated workforce it needs [43] [44] [45]. There is adequate confirmation from the research findings to suggest that vehicle replacement positively influences service delivery. The implication is that continuous improvement of vehicle acquisition and disposal of worn-out vehicles by SOEs results in improved service delivery. This finding is in correspondence with a number of prior related studies such as those by [11] [13] [37] [46]. It is also noted that the study is consistent with the central tenets of replacement theory and resource based view which emphasize on fleet availability and consideration of factors such as cost of running the fleet, repair and maintenance costs among others. Furthermore, the study findings provide adequate confirmation that ICT moderates the influence of vehicle fleet management practices on service delivery. This implies that an increase in ICT usage 
results in positive changes in vehicle fleet management practices and service delivery. Ref. [47], observed that ICT has the potential to transform public service delivery. Ref. [48], argue that this is only achievable when a public sector organization knows what the ICT is being used for and whether the appropriate ICT is being used. ICT is seen to be a lever for the transformation of public entities by creating viable internet presence to respond quickly to customers' needs [49].

\section{Conclusions and Implications}

The study investigated the influence of vehicle fleet management practices on service delivery in SOEs. The conclusions for this study are based on research objectives, questions and hypothesis. The study concludes that there is poor vehicle spare parts management and that vehicle faults are not replaced until failure occurs thus negatively influence service delivery. The study also concludes that fuel consumption rate, fuel monitoring, and fuel sourcing and allocation have influenced negatively service delivery within SOEs in Zimbabwe. The study concludes that lack of driver training and education, lack of regular driver forums, poor recognition and rewarding of drivers have negatively influence service delivery within SOEs. The study concludes that unclear procedures for disposal, acquisition of vehicles, lack of procurement planning, little consideration to vehicle life span and abandonment of fleet needing disposal have influenced negatively service delivery in SOEs. The study established that ICT strengthens the positive relationship between vehicle fleet management practices and service delivery. Therefore, the study concludes that when the level of ICT usage is high in SOEs, vehicle maintenance, fuel management, driver management, vehicle replacement and service delivery are enhanced.

The outcomes of the study demonstrate that vehicle fleet management practices influence service delivery. Although prior related studies have examined vehicle fleet management practices across many countries, majority of these studies have explored the impact of vehicle fleet management on disaster and relief responses, and the overall humanitarian logistics perspective, [50] [51] [52] [53] [54]. This, therefore, shows that there is a research gap that needs to be filled with appropriate research. The contribution of the study is that vehicle fleet management practices influence service delivery in SOEs. In addition, there is insufficient evidence of studies that focused on the moderation effect of ICT on the influence of vehicle fleet management practices on service delivery. [55], posit that ICT plays a crucial role in reducing fuel usage, safety, improve start or stop time, monitoring and assisting with efficient routing, eliminates after hours' usage and storm management. [56], assert that ICT has provided an adequate platform for the adoption of vehicle fleet management. The contribution of the current study, therefore, is demonstrating that ICT moderates the influence of vehicle fleet management practices on service delivery.

Relying on the study findings, it is crucial that fleet custodians in SOEs should 
be aware of the importance of preventive maintenance as a key ingredient in reducing vehicle breakdowns and enhancing service quality. On the other end, ICT can be used to address fitting of inferior spares and ensure parts reach the intended destinations. In addition, fleet managers should take careful actions on ensuring that drivers understand that they are responsible and accountable for their actions, improving driver recruitment procedures, educating and coaching drivers about vehicle standards and visual inspections. Besides, holding regular monthly driver forums and encouraging honest reporting, SOEs should motivate drivers in order to enhance service delivery. Also, a debriefing of drivers must be on the cards and religiously implemented. Incentives should be awarded to the drivers and maintenance staff for dedicated service and assisting in controlling and reducing breakdowns. To ensure discipline and effective work flow in the SOEs, policy makers should put in place measures to ensure that all employees comply with the fleet management policies and appropriate penalties be meted on staff who go against the policies. Simultaneously, policy makers should ensure that over-aged vehicles are withdrawn from the transport pool and be replaced with new ones to reduce frequent breakdowns, high maintenance cost and high fuel consumption.

\section{Conflicts of Interest}

The authors declare no conflicts of interest regarding the publication of this paper.

\section{References}

[1] World Bank Group (2018) 2017 Survey of National Development Banks. World Bank Group, Washington DC.

http://documents.worldbank.org/curated/en/977821525438071799/2017Survey-ofNational-development-banks

[2] Organization for Economic Co-Operation and Development (OECD) (2015) StateOwned Enterprises in the Development Process. OECD, Paris.

[3] Asian Development Bank Institute (2017) Policy Workshop for Efficient Management of State-Owned Enterprises. ADBI Policy Brief. No. 2017-4.

[4] Li, S., Lin, Y.C. and Selover, D.D. (2014) Chinese State-Owned Enterprises: Are They Inefficient? The Chinese Economy, 47, 81-115.

[5] Setino, R. and Ambe, I.M. (2016) Supply Chain Management Practices in State-Owned Enterprises Environment. Risk Governance and Control: Financial Markets \& Institutions, 6, 380-391. https://doi.org/10.22495/rcgv6i4c3art3

[6] Fourie, D. and Malan, C. (2020) Public Procurement in the South African Economy: Addressing the Systemic Issues. Sustainability, 12, Article No. 8692.

https://doi.org/10.3390/su12208692

[7] Kersten, W., Schröder, M. and Indorf, M. (2017) Potenziale der Digitalisierung für das Supply Chain Risikomanagement: Eine empirische Analyse. In: Seiter, M., Grünert, L. and Berlin, S., Eds., Betriebswirtschaftliche Aspekte von Industrie 4.0. ZfbF-Sonderheft, Springer Gabler, Wiesbaden, 47-74.

https://doi.org/10.1007/978-3-658-18488-9_3 
[8] Lavrinec, P. (2019) "The Most Prominent and at the Same Time Most Harmful": D. D. Bokhan in Wilno (1921-1923). Literatūra, 61, 10-22. https://doi.org/10.15388/10.15388/litera.2019.2.1

[9] Mutize, M. and Tefera, E. (2020) The Governance of State-Owned Enterprises in Africa: An Analysis of Selected Cases. Journal of Economics and Behavioral Studies, 12, 9-16. https://doi.org/10.22610/jebs.v12i2(J).2992

[10] Fourie, D. and Poggenpoel, W. (2016) Public Sector Inefficiencies: Are We Addressing the Root Causes? South African Journal of Accounting Research, 31, 169-180. https://doi.org/10.1080/10291954.2016.1160197

[11] Assey, T.B., Kalegele, K. and Chachage, B. (2017) Factors Influencing Fixed Assets Losses in Local Government Authorities in Tanzania. African Journal of Business Management, 11, 69-73. https://doi.org/10.5897/AJBM2016.8210

[12] Controller Auditor General, National Audit Office (2018) The Annual General Report of the Controller and Auditor General on the Audit of Financial Statements of the Central Government for the Financial Year Ended 30th June 2018.

[13] Ampiah, M.O. (2018) Challenges of Vehicle Fleet Management and Control in the University Education, Winneba, Ghana. International Journal of Engineering and Advanced Technology Studies, 6, 15 p. https://www.eajournals.org/

[14] Naief, A. (2017). Physical Asset Management Practices in the Saudi Public Sector. Built Environment Project and Asset Management, 7, 19-31. https://doi.org/10.1108/BEPAM-12-2015-0070

[15] Government of Zimbabwe, Ministry of State Enterprises and Parastatals (2012) Restructuring Procedures Manual, Zimbabwe.

[16] Mutanda, D. (2014) The Impact of the Zimbabwean Crisis on Parastatals. International Journal of Politics and Good Governance, 5, 14 p.

[17] Rusvingo, S.L. (2014) The Salary-Gate Scandal in the Zimbabwe Parastatals Sector: Another Darkside of the Nation (2013-2014). Global Journal of Management and Business Research: Administration and Management, 14, 19-29.

[18] Hadebe, S., Mandaza, I., Moyo, G., Mutondoro, F. and Ncube, M.J. (2015) Annual State of Corruption Report: Focus on State-Owned Enterprises. Transparency International Zimbabwe.

[19] Emily, M. and Muyengwa, G. (2021) Maintenance of Municipality Infrastructure: A Case Study on Service Delivery in Limpopo Province at South Africa. American Journal of Operations Research, 11, 309-323. https://doi.org/10.4236/ajor.2021.116019

[20] Report of the Auditor-General for the Financial Year Ended December 31, 2018 on Appropriation Accounts, Finance and Revenue Statements and Fund Accounts. https://www.auditorgeneral.gov.zw/phocadownload/Ministries-and-departments/A G\%20REPORT\%202018\%20ON\%20APPROPRIATION\%20ACCOUNTSFINANCE \%20ACCOUNTSREVENUE\%20STATEMENTS\%20AND\%20FUND\%20ACCOUN TS.pdf

[21] Parliamentary Committee on Transport and Infrastructure Development (2017) The Portfolio Committee on Transport and Infrastructural Familiarization Tour of Victoria Falls And Harare Airports and the Plumtree-Bulawayo-Harare. Mutare Road Project.

[22] Ministry of Finance and Economic Development (2021) The 2021 National Budget Statement.

[23] Shoko, E. and Naidu, M. (2020) Political Conflict and Community Health in Zim- 
babwe: Health Professionals' Perspectives. Africa's Public Service Delivery and Performance Review, 8, 8. https://doi.org/10.4102/apsdpr.v8i1.414

[24] Creswell, J. (2014) Research Design: Qualitative, Quantitative, and Mixed Methods Approaches: 4th Edition, SAGE Publications Inc., London.

[25] Bryman, A. and Bell, E. (2015) Business Research Methods. Oxford University Press, Oxford.

[26] Field, A.P. (2009) Discovering Statistics Using SPSS . SAGE Publications, Thousand Oaks.

[27] Atalay, M., Anafarta, N. and Sarvan, F. (2013) The Relationship between Innovation and Firm Performance: An Empirical Evidence from Turkish Automotive Supplier Industry. Procedia-Social and Behavioral Sciences, 75, 226-235.

[28] Bagozzi, R.P. and Yi, Y. (1988) On the Evaluation of Structural Equation Models. Journal of the Academy of Marketing Science, 16, 74-94.

https://doi.org/10.1007/BF02723327

[29] Hooper, D., Coughlan, J. and Mullen, M. (2008) Structural Equation Modelling: Guidelines for Determining Model Fit. Electronic Journal of Business Research Methods, 6, 53-60.

[30] Hu, L.T. and Bentler, P.M. (1999) Cutoff Criteria for Fit Indexes in Covariance Structure Analysis: Conventional Criteria versus New Alternatives. Structural Equation Modeling, 6, 1-55.

[31] Reisinger, Y. and Mavondo, F. (2007) Structural Equation Modeling. Journal of Travel \& Tourism Marketing, 21, 41-71.

[32] Henseler, J., Ringle, C.M. and Sarstedt, M. (2014) A New Criterion for Assessing Discriminant Validity in Variance-Based Structural Equation Modeling. Journal of the Academy of Marketing Science, 43, 115-135. https://doi.org/10.1007/s11747-014-0403-8

[33] Ragab, M. and Arisha, A. (2017) Research Methodology in Business: A Starter's Guide. Management and Organizational Studies, 5, 23 p.

[34] Aflabo, J., Kraa, J.J. and Agbenyo, L. (2020) Examining the Effect of Fleet Management on Competitive Advantage in the Transport Industry. European Journal of Logistics, Purchasing and Supply Chain Management, 8, 7-23. https://doi.org/10.37745/ejlpscm/vol8.no2.pp7-23.2020

[35] Ambaye, T. (2019) Assessment of Fleet Management Practices in Bottled Water Companies and Its Implication for Operational Performance: Case of Aqua Addis Bottled Water Company-Asku Plc. Addis Ababa University, Addis Ababa.

[36] Zacharof, N.G. and Fontaras, G. (2016) Review of in Use Factors Affecting the Fuel Consumption and $\mathrm{CO}_{2}$ Emissions of Passenger Cars. JRC Science for Policy Report.

[37] Gitahi, M.P. and Ogollah, K. (2014) Influence of Fleet Management Practices on Service Delivery Performance to Refugees in United Nations High Commissioner for Refugees Kenya Programme. European Journal of Business Management, 2, 336-341.

[38] Pedraza-Martinez, A.J. and Van Wassenhove, L.N. (2012) Transportation and Vehicle Fleet Management in Humanitarian Logistics: Challenges for Future Research. EURO Journal on Transportation and Logistics, 1, 185-196.

https://doi.org/10.1007/s13676-012-0001-1

[39] Ally, D. (2020) Factors Affecting Motor Vehicle Fleet Management in Public Institution in Tanzania, a Case of the Ministry of Finance and Planning. Mzumbe University, Dar es Salaam. 
[40] Chigumira, G., Chipumho, E. and Chiwunze, G. (2020) Fiscal Transparency and Accountability within the Context of Devolution in Zimbabwe. Zimbabwe Economic Policy Analysis and Research Unit (Issue April).

[41] Gasela, M. (2021) The Impact of Strategy Lignment on Organizational Performance in National Public Entities in the Northern Cape Province of South Africa. Africa's Public Service Delivery and Performance Review, 9, 9.

https://doi.org/10.4102/apsdpr.v9i1.489

[42] Chiparo, J.P., Tukuta, M. and Musanzikwa, M. (2021) Vehicle Fleet Management Practices: A Systematic Review. International Journal of Advanced Research, 9, 1287-1291. https://www.journalijar.com/ https://doi.org/10.21474/IJAR01/13679

[43] Tseng, C.M., Chang, H.L. and Woo, T.H. (2013) Modeling Motivation and Habit in Driving Behavior under Lifetime Driver's License Revocation. Accident Analysis \& Prevention, 51, 260-267. https://doi.org/10.1016/j.aap.2012.11.017

[44] Davidescu, A.A.M., Apostu, S.A., Paul, A. and Casuneanu, I. (2020) Work Flexibility, Job Satisfaction, and Job Performance among Romanian Employees-Implications for Sustainable Human Resource Management. Sustainability, 12, Article No. 6086. https://doi.org/10.3390/su12156086

[45] United Nations (2020) Recovering Better: Economic and Social Challenges and Opportunities. Department of Economic and Social Affairs, United Nations, New York.

[46] Njeru, S.W. and Moronge, M. (2018) Effects of Asset Disposal Practices on Performance of State Owned Enterprises in Kenya. The Strategic Journal of Business \& Change Management, 5, 660-675.

[47] Alahakoon, M.U.I. and Jehan, S.N. (2020) Efficiency of Public Service Delivery-A Post-ICT Deployment Analysis. Economies, 8, Article No. 97.

https://doi.org/10.3390/economies8040097

[48] Cruzat, C and Kopsidas, K. (2019) Reliability Evaluation of ICT Used on Dynamic Line Rating for Power System Flexibility. 2019 IEEE Milan PowerTech, Milan, 23-27 June 2019, 1-6. https://doi.org/10.1109/PTC.2019.8810609

[49] Erdoğan, K. and Villi, B. (2021) Transformation of Tourism and Hospitality Customers' Perception of Risk and Customers' Needs for Control. Journal of Multidisciplinary Academic Tourism, 6, 117-125.

[50] Balcik, F., Beamon, G. and Smilowitz, A. (2008) Performance Measurements in Humanitarian Relief Chains. International Journal of Public Sector Management, 21, 4-25. https://doi.org/10.1108/09513550810846087

[51] Martinez, A.J.P., Stapleton, O. and Van Wassenhove, L.N. (2011) Field Vehicle Fleet Management in Humanitarian Operations: A Case-Based Approach. Journal of Operations Management, 29, 404-421. https://doi.org/10.1016/j.jom.2010.11.013

[52] Begashaw, M. (2018) The Effect of Fleet Management on Fleet Efficiency on Operational Efficiency. Thesis Submitted to the Department of Logistics and Supply Chain Management, University of Addis Ababa, Addis Ababa.

[53] Yin, R.Y., Liu, Z.Y. and Fu, X. (2019) Vehicle Routing Strategy for Disaster Relief Operation: A Case Study. CICTP 2019, American Society of Civil Engineers. https://doi.org/10.1061/9780784482292.234

[54] Gökçe, M.A and Ercan, E. (2019) Multi-Period Vehicle Routing \& Replenishment Problem of Neighborhood Disaster Stations for Pre-Disaster Humanitarian Relief Logistics. IFAC-PapersOnLine, 52, 2614-2619.

https://doi.org/10.1016/j.ifacol.2019.11.601 
[55] Kuei, C., Madu, C.N., Chow, W.S. and Lu, M.H. (2005) Supply Chain Quality and Excellence in the New Economy: An Empirical Study of Hong Kong Based Firms. Multinational Business Review, 13, 33-53. https://doi.org/10.1108/1525383X200500002

[56] De Souza, F., Gurumurthy, K., Auld, J. and Kockelman, K. (2020) An Optimization-Based Strategy for Shared Autonomous Vehicle Fleet Repositioning. Proceedings of the 6 th International Conference on Vehicle Technology and Intelligent Transport Systems, Prague, 2-4 May 2020, 7 p. 